\title{
PRINSIP-PRINSIP KEUANGAN ISLAM MENURUT ABDULLAH SAEED
}

\author{
Sofyan Sulaiman \\ Keuangan HPA Indonesia, Cabang Pekanbaru, Riau
}

\section{Abstract}

In the late 60s to early 70s, was born a consensus of Islamic law and economic experts who say that the interest in the banking system is part of usury, so the banks are not in accordance with the Islamic Shari'ah. As an alternative, the experts offer free banking model of the system of interest, with the concept of profit and loss sharing (PLS). However, the presence of Islamic banking bore the pros and cons among Muslim scholars. Among the leaders of the cons is Abdullah Saeed. This article discusses the thinking Abdullah Saeed who criticize the interpretation of usury and interest, the principle of PLS (mudarabah and loss), and the principle of sale (murabaha). The criticism is: (1) He said, usury is forbidden because of the exploitation of the poor, while the interest there is no element of exploitation so that interest is not included in the category of usury. (2) A number of requirements in practice only to protect banking PLS. So what happens is sharing the results, but do not share the risk. (3) Further Saeed see that Islamic banking is not better than conventional banking. Because in fact, the practice of Islamic banking also implement a "model of financial transactions such as interest" ie Murabaha. Murabaha profit are uncertain and affected by time, not much different from the concept of interest reproach.

\section{تجريل}

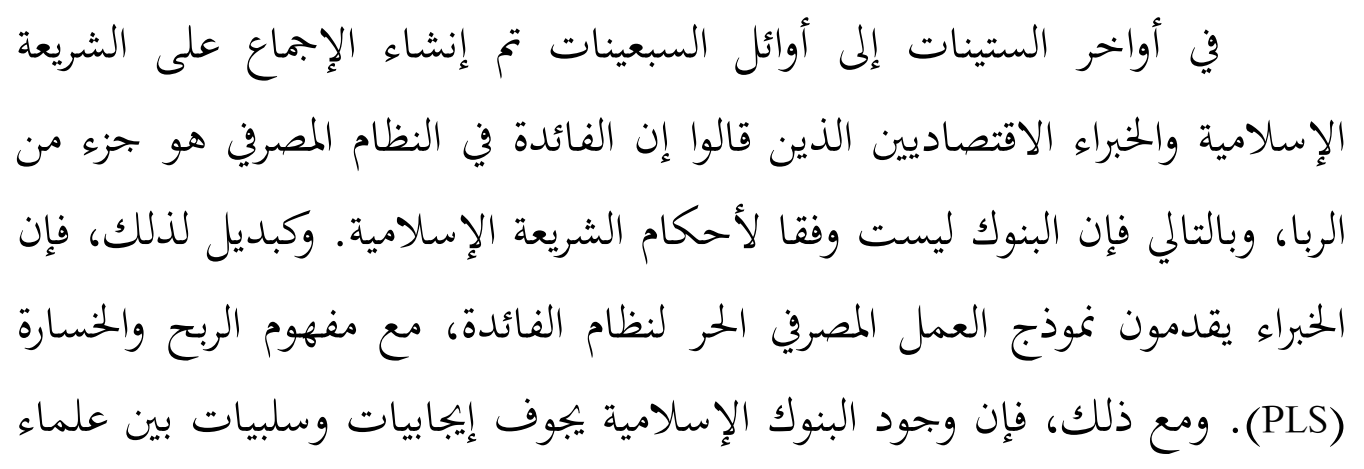


المسلمين. ومن زعماء سلبيات هو عبد الله سعيد. هذه المقالة تتناول التفكير لعبد الله سعيد الذي ينتقد تفسير الربا والفائدة، ومبدأ PLS (المضاربة والخسارة)، ومبدأ البيع (المرابحة). وأما الانتقادات فهي: (1) قال: الربا حرام بسبب استغلال الفقراء حيث أن الفائدة ليست فيها عنصر الاستغلال فلا تتضمن الفائدة في طبقة الربا. (r) هناك عدد من المتطلبات في التطبيق فقط لحماية PLS المصرئ. فما يهدث هو تقاسم المحاصيل وليس تقاسم المخاطر. (rا) ومن ثم، رأى سعيد أن البنوك الإسلامية ليست أفضل من البنوك التقليدية، إذ أن في الحقيقة، كان العمل في المصارف الإسلامية يطبق أيضا "نموذج المعاملات المالية مثل الفائدة" أي المرابحة. وأرباح المرابحة غير مؤكدة وتتأثر بالوقت، ولا تختلف كثيرا عن مفهوم أعتاب الفائدة.

Keywords: Perbankan Islam, Riba, Bunga Bank, Muḍārabah, Musyārakah, dan Murābahah

\section{A. Pendahuluan}

Semenjak dimulainya sejarah Islam, masyarakat Muslim tidak pernah mengabsahkan riba (termasuk di dalamnya bunga). Masyarakat Muslim mengelola perekonomiannya dan menyelenggarakan perdagangan domestik dan internasionalnya tanpa pranata bunga. Bagi-hasil dan berbagai jenis sistem partisipasi beperan sebagai dasar yang layak bagi tabungan dan investasi, serta cukup banyak modal yang dihimpun untuk kepentingan pertambangan, pembangunan kapal, tekstil dan industri-industri lainnya, seperti halnya untuk kepentingan perdagangan maritim. Masyarakat Muslim mengenal perbankan berdasarkan bunga ketika rezim-rezim kolonial menjajah negara-negara Muslim. ${ }^{1}$ Tidak adanya sistem keuangan Islam saat itu, memaksa masyarakat Muslim untuk menerima sistem berbasis bunga tersebut, hampir mustahil usaha berkembang tanpa keterlibatan perbankan berdasarkan bunga. Keberadaan

1 Muhammad Nejatullah al-Siddiqi, Bank Islam (Bandung: Penerbit Pustaka, 1984), hal. xiv. 
perbankan berdasarkan bunga ini merespon beberapa ulama dan cendikiawan Muslim. Ada yang menerima bunga tersebut berdasarkan kebutuhan, ada juga yang berusaha membedakan bunga bank dengan riba, sebagai implikasinya bunga bank boleh dan sah dilakukan. Dan yang terakhir, menolak total sistem bunga tersebut karena bunga dan riba tak ada bedanya. Sehingga pelarangan total riba di dalam naș juga berlaku sama terhadap bunga.

Sejalan dengan hegemoni rezim kolonial terhadap dunia Islam pada saat itu Pada akhir abad $18 \mathrm{M}$ dan awal abad $19 \mathrm{M}$ muncul gagasan pembaharuan Islam. Gerakan ini pada awalnya digagas oleh Jamaluddin al-Afghani (1839-1897 M) yang kemudian dilanjutkan oleh Muhammad Abduh (1849-1905 M). Gerakan pembaharauan (revivalis) ditandai dengan kebangkitan negeri-negeri jajahan Eropa. Gagasan pembaharuan timbul dari kondisi internal umat Islam yang secara umum ditandai dengan memudarnya semangat keilmuan umat Islam, ke-jumud-an di bidang intelektual, sikap taqlid umat Islam, dan berkembang pesatnya tradisi syirik yang tidak bisa diabaikan begitu saja. Kemudian dari faktor eksternal, kehadiran Bangsa Eropa yang menjajah negeri-negeri Islam sehingga memicu respon dari cendekiawan Islam. ${ }^{2}$ Adapun ide-ide yang dibawa meliputi pembaharuan intelektual dan politik agama, serta unifikasi politik di bawah satu pemimpin utama. ${ }^{3}$ Gerakan revivalis kemudian pada abad ke-20 menjelma menjadi gerakan neo-Revivalis. Gerakan neo-Revivalis ini lah yang telah paling banyak mempengaruhi perkembangan teori perbankan Islam. Teori ini dikembangkan secara luas guna mempraktikkan interpretasi tradisional riba (yang dianut oleh kaum neo-Revivalis) di bidang perbankan dan pembiayaan. ${ }^{4}$

Dalam perkembangannya, perbankan Islam bergerak kearah pragmatis, hal inilah kemudian yang memicu respon seorang cendikiawan Muslim liberal, Abdullah Saeed. Saeed merupakan Professor Studi Arab dan Islam di Universitas Melbourne Australia, sekaligus menjabat sebagai Direktur Pusat Studi Islam Kontemporer di Universitas Melbourne. ${ }^{5}$ Saeed, melihat

\footnotetext{
2 K. Hitti, History of The Arabs, (Jakarta: Serambi, 2006) hal. 965.

3 Ibid., hal. 966

4 Abdullah Saeed, Menyoal Bank Syariah: Kritik atas Interpretasi Bunga Bank Kaum NeoRevivalis (Jakarta: Paramadina, 2004), hal. 6.

5 http://www.abdullahsaeed.org/about-me, di akses pada hari Senin, 11 Maret 2013, jam 12.30 WIB
} 
bahwa dalam perbankan Islam terdapat transaksi-transaksi yang unsur-unsur bunganya tidak eksplisit, atau dikenal dengan suatu nama yang selain dari bunga, seperti dalam kasus opsi mata uang, operasi-operasi komersial jangka pendek dengan mud̄ārabah, musyārakah, dan muräbaḥah, sepenuhnya dapat diterima dengan kedok "upah", dan "laba". Hal ini menjadi lengkap dengan memberikan penekanan lebih pada definisi legal atas kontrak dan transaksi, dan dengan menekankan pada makna literal teks-teks syariah yang terkait dengan masalah riba.

Menurut Saeed pangkal masalah dari ini semua adalah interpretasi tradisional riba yang sudah diterima sepenuh hati oleh kaum noe-Revivalis menghadapi kendala-kendala tak terpecahkan di lingkungan finansial dan ekonomi dewasa ini, karena tampaknya tak bisa diterapkan sepenuhnya, dan secara moral pun tak bisa dibenarkan. Kebanyakan mekanisme terpenting yang direncanakan bank Islam untuk menerapkan interperasi tradisional riba tidak tampak lebih hebat dari mekanisme-mekanisme yang ditolak karena dianggap mengandung unsur riba. Melihat hal inilah menurut Saeed perlu mengkaji ulang interpretasi riba dengan pendekatan moral dan kemanusiaan. ${ }^{6}$

Abdullah Saeed mencoba menawarkan konsep keuangan Islam yang sangat berbeda dari mayoritas ahli ekonomi Islam dan ulama. Saeed menawarkan pendekatan yang lebih berorientasi mașlăhah, ${ }^{7}$ dalam kesempatan yang lain, Saeed mengatakan pendekatan liberal. ${ }^{8}$ Menurutnya, nas yang berkaitan dengan prinsip-prinsip keuangan Islam harus dipahami bagaimana konteks ayat (atau hadits) di turunkan.

Pendekatan liberal mencoba menjelaskan riba dengan makna yang sangat berbeda dari mainstream ahli ekonomi Islam, menurut pandangan ini, bunga tidak termasuk dari defensi riba. Asalkan bank-bank konvensional menerapkan prinsip-prinsip etika dan mampu menyediakan jasa keuangan bagi umat Islam, maka ia telah sejalan dengan prinsip-prinsip Islam. ${ }^{9}$ Pendekatan liberal inilah

\footnotetext{
6 Saeed, Menyoal..., hal. xv-xvii.

7 Abdullah Saeed, "Idealism and Pragmatism in Islamic Banking: The Application of Shari'ah Principles and Adjustments", Journal of Arabic, Islamic and Middle Eastern Studies, No. 2, Vol. 4 (1998), hal. 89.

8 Abdullah Saaed, "Islamic Banking and Finance: In Serch of a Pracmatic Model", dalam buku Islamic Perspectif on the New Millenium, Virgina Hooker dan Amin Saikal (ed.) (Singapore: Institute of Southeast Asian Studies, 2004), hal. 116.
}

9 Ibid. 
kemudian yang diusung oleh Abullah Saeed. Selanjutnya dalam penelitian inilah kemudian akan dibahas pemikiran Saeed mengenai konsep keuangan Islam.

\section{B. Sekilas Tentang Abdullah Saeed dan Posisi Pemikirannya}

Abdullah Saeed dilahirkan di Maladewa (Maldives), sebuah negara kecil yang berbentuk republik, terletak di sebelah selatan-barat daya India, sekitra $700 \mathrm{~km}$ barat daya Sri Langka. ${ }^{10}$ Ia merupakan keturunan suku bangsa Arab Oman yang bermukim di Maladewa. Pada tahun 1977 hijrah ke Arab Saudi untuk menuntut ilmu di sana dan mengambil studi bahasa Arab di Universitas Islam Madinah diselesaikan pada tahun 1979. Pada tahun 1979-1982 mengambil ijazah Sekolah Menengah di Institute Menegah Madinah-Arab Saudi. Pada tahun 1982-1986, Abdullah Saeed meraih BA (Bachelor of Arts) dalam Studi Arab dan Islam di Universitas Islam Madinah. Tahun berikutnya, Saeed meinggalkan Arab Saudi untuk belajar di Australia. Di negara kanguru ini, Saeed memperoleh beberpa gelar akademik, hingga ia mengajar dan menjadi Direktur Pusat Studi Islam Kontemporer di Universitas Melbourne.

Dalam banyak tulisan, ia mengakui dirinya sebagai kontekstualis, Menurutnya kontekstualis memiliki pendekatan yang lebih bernuasa dalam mencari makna al-Qur'an, walaupun pendektan ini rinciannya sering berbeda diantara para sarjana. Secara umum karakterinstik para sarjana kontekstual adalah mereka beragumen bahwa makna khusus dari alqur'an (atau hadits) pada tingkat yang luas tak tentu. Makna, dalam konteks ini berkembang dari waktu ke waktu dan tergantung pada konteks sosio-historis, budaya dan bahasa teks. ${ }^{11}$ Lebih lanjut Saeed mengatakan:

Alasan saya menggunakan (pendekatan kotekstual), adalah menuju pendekatan yang lebih fleksibel dalam menafsirkan teks-teks dengan mempertimbangkan baik dalam konteks sosio-historis Qur'an pada saat wahyu pada abad pertama maupun memperhatikan dan kebutuhan umat Islam kontemporer. Minat utama saya adalah bagaimana makna Qur'an dapat berhubungan dengan kehidupan Muslim, dalam arti aplikasi untuk dipraktekan setiap hari dalam

10 http://id.wikipedia.org/wiki/Maladewa, diakses pada jam 12:52 WIB, Jum'at 10 Mei 2013.

11 Abdullah Saeed, The Qur'an: An Introduction (Routledge: Oxon, 2008), hal. 221. 
waktu, keadaan dan tempat yang berbeda, terutama yang berkaitan dengan mempertimbangkan dan kebutuhan periode modern. ${ }^{12}$

Saeed menyebutkan beberapa tokoh yang masuk dalam kateogori tersebut, seperti, Fazlur Rahman, Aminah Wadud, Muhammad Syahrour, Muhammad Arkoun, dan Khalid Abu al-Fadl. Rahman memberi pengaruh yang besar bagi pemikiran Saeed. Dalam beberapa tulisannya, secara tegas atau paling tidak menyinggung bahwa pada dasarnya proyek tafsir yang digagasnya banyak dipengaruhi oleh Fazlur Rahman. Bahkan Rahman dianggap penggagas inti dari metode tafsir yang ditawarkannya. Saeed mengakui kontribusi original dalam menafsirkan ayat-ayat ethico-legal. Kemudian yang paling penting menurut Saeed, Rahman telah memainkan peran kunci dalam gagasan terkait dengan hermeneutika dengan studi Islam. ${ }^{13}$

Jika kegelisahan Rahman sangat bersinggungan dengan keagamaan umat Islam dalam menghadapi modernitas. Dalam kaitan dengan tafsir al-Qur'an, Rahman menolak pendekatan tradisional dalam penafsiran al-Qur'an, baik tradisi ushul fiqh maupun tradisi tafsir. Rahman menganggap para tradisional tekstualis mempertahankan al-Qur'an secara atomistis dan pada dasarnya tidak melakukan apapun untuk mahami al-Qur' an. ${ }^{14}$ Maka kegelisahan Saeed adalah maraknya model penafsiran tektual yang mengabaikan konteks pewahyuan maupun penafsiran. Melalui kacamata inilah ia membangun sebuah model tafsir yang peka konteks.

Dari penjelasan ini dapat dipahami bahwa saeed memandang penting penelusuran historis terhadap situasi sosial ketika wahyu diturunkan dalam rangka menggali dan menemukan tujuan moral dan prinsip yang dikandungnya. Tujuan moral dan prinsip-prinsip inilah yang sangat berperan dalam mempengaruhi perubahan sosial ke arah yang kondusif bagi umat Islam. Mesikipun memandang penting tujuan moral dan prinsip al-Qur'an, perubahan sosial masa kini juga perlu dipertimbangkan ketika menetapkan suatu hukum.

12 Abdullah Saeed, Interpreting the Qur'an: Toward a Contemporary Approach (Madison Ave: Routladge, 2006), hal. 1.

13 Ibid., hal. 222.

14 Fazlur Rahman, Islam dan Modernitas: Tentang Transformasi Intelektual (Bandung: Pustaka, 1986) hal. 2. 


\section{Prinsip-Prinsip Keuangan Islam menurut Abdullah Saeed}

Pada pertengahan abad ke-20, Perbankan Islam dibahas secara serius oleh para sarjana Muslim. Nejatullah Siddiqi merupakan cendikiawan Muslim yang pertama menulis tentang perbankan Islam dengan judul "Banking without Interest" (1969 dalam bahasa Urdu dan 1973 dalam bahasa Inggris), kemudian Syed Abdul A'la al-Maududi dengan judul "Riba", Ahmad Irsyad dengan "Banking Without Interest"15, dan lain-lain. Para teoritisi perbankan dan fuqaha periode ini menegaskan bahwa perbankan Islam adalah perbankan bebas bunga yang didasarkan pada konsep profit and loss sharing (PLS) atau bagi hasil. Mereka juga menegaskan dan menyumbangkan teori bahwa bunga adalah riba. Dengan menafsirkan bunga sebagai riba, para teoritisi perbankan Islam menganut konsep awal bahwa setiap keuntungan yang ditambahkan atas pinjaman bagi pemberi pinjaman adalah riba. Sehingga setiap yang ditambahkan atas pinjaman yang diberikan kepada kreditur, baik itu dalam bentuk nominal atau riil adalah riba.

Namun dalam perkembangannya, menurut Saeed, terjadi perbedaan antara teori dan praktik. Sebagai contoh, pengecaman terhadap nilai-waktu pada uang (time value of money), namun di pihak lain adalah penggunaan nilai waktu ini dalam skala yang lebih luas untuk perhitungan batas laba (profit margin) dan keuntungan dana yang disalurkan perbankan (pembiayaan murābahah). PLS yang pada awalnya dijadikan rule model Perbankan Islam hanya diterapkan pada investasi jangka pendek yang nyaris tidak ada bedanya dengan pembiayaan yang keuntungannya ditetapkan dimuka. ${ }^{16}$

Menyikapi hal ini, Abdullah Saeed berupaya untuk mengoreksi konsep keuangan Islam yang dikembangkan selama ini. Menurutnya harus ada sudut pandang baru terhadap konsep-konsep keuangan Islam yang berdasarkan pada seluruh ajaran al-Qur'an dan Sunnah, dan dengan perspektif realistas ekonomi dan finansial kontemporer. ${ }^{17}$ Ia menawarkan pendekatan yang berorientasi mașlahah. Untuk memahami perbankan bebas riba, riba tidak boleh ditafsirkan sebagai bebas bunga. Sebuah perbankan bisa menjadi syariah selama dia

15 Ahmed Abdel Fattah el-Ashker dan Rodney Wilson, Islamic Economic: Short History (Leiden-Boston: Brill, 2006), hal. 366.

16 Abdullah Saeed, Menyoal Bank Syariah, Kritik Interpretasi Bunga Bank Kaum Noe-Revivalis (Jakarta: Paramadina, 2006), hal. xvi.

17 Ibid., hal. xvii. 
mengandung (1) nilai-nilai keadilan, keseteraan, kejujuran, non-eksploitasi beserta prinsip-prinsipnya. (2) Bentuk yang lebih manusiawi, dimana keuangan Islam melayani yang "membutuhkan", dan (3) membantu kelas ekonomi yang kurang beruntung untuk menghidupkan taraf hidup mereka. ${ }^{18}$

Dalam hal ini Saeed menawarkan konsep baru dari keuangan Islam yang sangat berbeda dengan mainstream dari pemikir dan ulama ekonomi Islam. Paling tidak ada tiga hal yang di koreksi oleh Saeed, yaitu: konsep riba, prinsip bagi-hasil (mudārabah dan musyārakah), dan prinsip jual beli (murābahah).

\section{Konsep Riba}

\section{a. Konteks Pengharaman Riba}

Sebagaimana dijelaskan sebelumnya, perbankan Islam menerima bahwa bunga bank merupakan salah satu bentuk riba. Mayoritas Muslim yakin bahwa interpretasi ini seperti yang terdapat dalam fiqh adalah interpretasi yang tepat dan harus diikuti. Seperti yang dinyatakan oleh Sayid Quthb, bahwa bunga bank dan bank telah makan "tulang dan daging" dari si miskin dan meminum "darah dari keringat" mereka di bawah payung sistem bunga. Kemudian al-Maududi juga menegaskan bahwa riba "merupakan jumlah bunga tetap yang diperoleh kreditur dari debitur. ${ }^{19}$ Namun pemahaman seperti ini, menurut Saeed, tidak mempertimbangkan tujuan moral dari pengharaman riba seperti yang dijelaskan dalam, atau dipahami dari al-Qur'an dan Sunnah. ${ }^{20}$

Saeed melihat, pengecaman dan pengharaman final atas riba dalam al-Qur'an didahului oleh pelarangan sejumlah bentuk perilaku lain yang secara moral tidak dapat diterima terhadap orang-orang yang secara sosial dan ekonomi tidak beruntung (mustad afin). Seperti, tidak menolong fakir miskin mendapatkan hukuman di neraka. ${ }^{21}$ Kritikan Allah terhadap orang yang tidak memberikan makan dan membantu orang miskin ${ }^{22}$. Dalam

18 Saeed, "Idealism and Pragmatism in Islamic Banking: The Application of Shari'ah Principles and Adjustments", Journal of Arabic, Islamic and Midle Eastern Studies, Vol. 4, No.2, 1988), hal. 89-111.
19 Ibid.
20 Saeed, Menyoal..., hal. 20.
21 QS. Al-Mudatsir (74): 43-44.
${ }^{22}$ (QS. Al-Mudatsir (74): 24-45. 
banyak kesempatan, al-Qur'an mengecam orang-orang yang berkelebihan di masyarakat Makkah. ${ }^{23}$ Al-Qur'an juga berulang-ulang pentingnya memberi nafkah untuk meringankan beban orang-orang miskin.

Menurut Saeed, hal tersebut menandakan keberpihakan al-Qur'an terhadap orang-orang yang secara ekonomi tidak beruntung, dan menyoroti perlunya memberikan bantuan keuangan terhadap mereka. Konteks ayatayat tesebut menunjukkan bahwa tindakan tolong-menolong semacam itu direkomendasikan dalam suatu kasus debitur yang terpaksa meminjam untuk memenuhi kebutuhan dasarnya. Tidak ada yang menunjukkan bahwa pinjam-meminjam di kalangan orang kaya untuk keperluan dagang, atau, dengan kata lain, untuk tujuan kemanusiaan. ${ }^{24}$

Konteks ayat-ayat tersebut dikaitkan oleh Saeed dengan ayat-ayat pelarangan riba, bahwa riba terkait dengan eksploitasi orang-orang yang lemah. Adapun ayat pertama yang mengharamkan riba:

Dan sesuatu riba (tambahan) yang kamu berikan agar dia bertambah pada harta manusia, maka riba itu tidak menambah pada sisi Allah. Dan apa yang kamu berikan berupa zakat yang kamu maksudkan untuk mencapai keridhaan Allah, maka (yang berbuat demikian) itulah orang-orang yang melipat gandakan (pahalanya). ${ }^{25}$

Saeed mengatakan tentang ayat ini, "Di sini al-Qur'an tampak tengah mengutuk praktik riba dan dampak eksploitasinya terhadap orang-orang yang malang di dalam masyarakat Makkah." ${ }^{26}$ Kemudian Saeed mengutip pendapat Fazlur Rahmah untuk memperkuat argumentsinya. Rahman mengatakan:

Sama sekali tidak aneh jika riba dikecam sejak periode awal pewahyuan; justru tidak munculnya kecaman yang demikian dini ini mungkin tidak hanya mengejutkan, tetapi juga berentangan dengan kebijakan al-Qur'an. Ayat-ayat Makkah penuh dengan kecaman terhadap ketidak adilan ekonomi masyarakat Makkah kala itu, terhadap 'kelintah-daratan" dan kekikiran orang-orang kaya, dan terhadap praktik-praktik dagan mereka yang tidak menghiraukan etika, seperti mencurangi timbangan dan ukuran, dll. Maka, bagaimana mungkin bahwa al-Qur'an akan lalai untuk mengecam kejahatan ekonomi riba?"27

\footnotetext{
${ }^{23}$ QS. Al-Fajr (89): 17-33.

24 Saeed, Menyoal..., hal. 24.

25 QS. Ar-Rum (30): 39.

26 Saeed, Menyoal..., hal. 26.

27 Fazlur Rhaman, "Riba and Interest", Journal of Islamic Studies (1964), hal. 3.
} 
Ayat kedua yang terkait dengan pelarangan riba telah diwahyukan di Madinah, setelah Perang Uhud dan hampir sebelas tahun setelah pengecaman riba yang bertama di Makkah: Hai orang-orang yang beriman, janganlah kamu memakan riba dengan berlipat ganda, dan bertakwalah kalian kepada Allah agar kalian medapatkan keberuntungan. ${ }^{28}$

Menurut Saeed, konteks ayat ini mengenai apa yang terjadi setelah Perang Uhud, dimana gugurnya tujuh puluh pria Muslim yang meninggalkan anak-anak yatim, para janda, dan orang-orang tua yang sudah lanjut usia dalam kondisi memerlukan bantuan finansial. ${ }^{29}$ Kemudian praktik riba yang terjadi pada waktu itu dinamakan dengan riba jahiliyyah. Hal ini berdasarkan komentar Imam Ath-Thabari mengenai ayat ini:

Janganlah mengonsumsi riba setelah kalian memeluk Islam sebagaimana kalian telah mengkonsumsinyas sebelum Islam. Cara orang-orang Arab pra-Islam mengkonsumsi riba adalah bahwa salah seorang dari mereka memiliki utang yang harus dilunasi pada tanggal tertentu. Ketika tanggal itu tiba, si kreditur menuntut pelunasan dari si debitur. Si debitur akan mengatakan, "Tundalah pelunasan utangku; aku akan memberikan tambahan atas hartamu." Inilah riba yang berganda dan berlipat ganda. ${ }^{30}$

Riwayat ini menunjukkan bahwa riba sebagaimana yang dipraktikkan pada zaman jahiliyyah (riba al-jahiliyyah) berarti penambahan jumlah dari pokok pinjaman sebagai imbalan penguluran jatuh tempo hutang yang sudah ada dikarenakan ketidakmampuan debitur untuk melunasinya tepat waktu. Riwayat ini menurut Saeed, menunjukkan bahwa tambahan atas utang terjadi setelah jatuh tempo karena ketidakmampuan si debitur memenuhi kewajibannya. Riwayat tersebut berbicara tetang utang tetapi tidak menyingkap apakah utang itu akibat dari pinjaman atau jual beli tunda. ${ }^{31}$ Lalu Saeed menyimpulkan, hal ini menjadi bukti bahwa konteks riba adalah eksploitasi terhadap orang-orang yang lemah.

Berkenaan dengan ayat “ .... Keadaan mereka yang demikian itu, adalah disebabkan mereka berkata (berpendapat), sesungguhnya jual beli itu sama dengan riba, padahal Allah telah menghalalkanjual beli dan mengharamkan

8 QS. Ali Imran (3): 130.

29 Saeed, Menyoal..., hal. 27.

30 Ibn Jarīr ath-Thabari, Jāmi'i al-Bayān 'an Ta'wīl Ayi al-Qur'ān (ttp.: Dār Hajr, 2001), V: 38.

1 Saeed, Menyoal..., hal. 29. 
riba...". ${ }^{32}$ Menurut Saeed, ayat yang menggabungkan dua pernyataan bahwa jual beli adalah halal dan riba adalah haram bukanlah pertentangan sebagaimana yang dipahami ulama dan para sarjana ekonomi Islam. Namun pertentangan yang muncul adalah pada ayat "Allah memusnahkan riba dan menyuburkan sedekah. Dan Allah tidak menyukai setiap orang yang tetap dalam kekafiran, dan selalu berbuat dosa." 33 Dua hal yang mendukung pandangan ini adalah, pertama, al-Qur'an tidak menyusulinya dengan anjuran jual-beli (bai') tetapi menyatakan kehalalaannya. Kedua, segera setelah pernyataan ini, Allah mempertentangkan antara riba dan sadaqah. ${ }^{34}$ Lebih lanjut, Saeed mengutip pendapat Rahman:

Menurut al-Qur'an, lawan dari riba bukan bai' (jual beli) melainkan shadaqah, kebingunangan yang tengah terjadi mengenai masalah ini, menurut kami, disebabkan karena riba dan bai' dianggap saling bertentangan. Akibatnya adalah bahwa "kekusutan-yuristis" (juristic hair-splitting) telah menggantikan pentingnya pesan moral di balik pengharaman riba. ${ }^{35}$

Setelah Allah mempertentangkan riba dengan shadaqah, al-Qur'an memerintahkan umat Islam untuk melepaskan hak mengambil riba yang masih ada dan untuk hanya menerima pokok pinjaman yang telah diberikan kepada debitur. Kegagalan untuk melakukan hal ini mengundang "perang dari Allah dan Rasulnya". Akhirnya, al-Qur'an menganjurkan umat Islam untuk memberikan waktu kepada debitur yang mendapatkan kesulitan (dzū 'usratin) untuk melunasi hutang tepat waktu. ${ }^{36} \mathrm{D} z \bar{u}$ 'usratin ini menurut sejumlah otoritas tafsir mengacu kepada orang miskin, bukan kepada orang kaya. Hal ini juga menjadi bukti bahwa al-Qur'an sangat berpihak kepada orang miskin.

Hai orang-orang yang beriman, bertakwalah kepada Allah dan tinggalkan sisa riba (yang belum dipungut) jika kamu orang-orang yang beriman. Maka jika kamu tidak mengerjakan (meninggalkan sisa riba), maka ketahuilah, bahwa Allah dan Rasul-Nya akan memerangimu. Dan jika kamu bertaubat (dari pengambilan riba), maka bagimu pokok hartamu; kamu tidak menganiaya dan tidak (pula) dianiaya. ${ }^{37}$

${ }^{32}$ QS. Al-Baqarah (2): 275.

QS. Al-Baqarah (2): 276.

34 Ibid., hal. 32

35 Rahman, Riba..., hal. 31.

36 Saeed, Menyoal..., hal. 33.

37 QS. Al-Baqarah (2): 278-279. 
Menurut Saeed, ada dua pernyataan penting yang terdapat dalam ayat-ayat terakhir (Al-Baqarah: 278-279) tentang riba barangkali dapat menjelaskan sifat riba sebagaimana yang dilarang dalam al-Qur'an. Pernyataan pertama adalah "lakum ru'ūsu amwālikum" (bagi kalian pokok pinjaman kalian) yang segera disusul dengan pernyataan "la tażlimūna wa la tuẓlamūn" (kalian tidak menganiayaa dan tidak pula dianiaya). Pernyataan pertama menyatakan bahwa hanya pokok pinjaman yang menjadi hak si kreditur dan, bagaimanapun juga, ini hanya satu sisi mata uang, sementara sisi yang lainnya adalah pernyataan kedua, la tazlimūn wa la tẓlamūn. Dua pernyataan tersebut tampak saling bergantung dan, oleh karena itu, salah satu pernyataan tidak boleh dilihat tanpa melihat pernyataan lainnya. Jika dua pernyataan tersebut diambil secara terpisah dan dengan mengabaikan salah satunya, akan ada bahaya bahwa makna yang dimaksud al-Qur'an kemungkinan terdistorsi. ${ }^{38}$

Sayangnya, menurut Saeed, karya-karya tafsir hanya menekankan satu sisi saja, "lakum ru'ūsu amwālikum," dan hampir sepenuhnya mengabaikan sisi kedua, "la tazlimūna wa la tuzlamun." Pengabaian pernyataan yang kedua mungkin mencerminkan metodologi yang digunakan oleh hampir semua mazhab hukum Islam yang metodologi itu elemen-elemen pembentuk setiap perintah dan larangan dalam al-Qur'an ditafsirkan dengan cara melihat makna yang paling literal dan paling dekat dengan teks yang relevan, dan menekankan aspek literal ini dengan mengabaikan alasan atau sebab yang mendasarinya. ${ }^{39} \mathrm{Hal}$ ini tercemin pada pandangan ar-Razi mengenai alasan pengharaman riba:

Pengharaman riba dibuktikan dengan sebuah teks [al-Qur'an]. Tidak penting bagi orang untuk mengetahui alasan dari kewajiban-kewajibannya. Oleh sebab itu, pengharaman riba harus dianggap telah cukup jelas diketahui meskipun kita tidak tahu alasan pengharaman ini. ${ }^{40}$

Pikiran utama yang ditekankan oleh Razi adalah bahwa pencarian alasan pelarangan tidaklah penting, orang hanya perlu taat. Lebih lanjut menurut pandangan ini, kita bahkan tidak perlu tahu apakah alasan itu ada. Padahal menurut Saeed alasan pengharaman tersebut penting agar

\footnotetext{
38 Saeed, Menyoal..., hal. 34.

39 Ibid., hal. 34.

40 Ibid.
} 
memperoleh pandangan yang berimbang mengenai apa yang termasuk riba dan apa yant tidak. ${ }^{41}$

Hal yang senada juga pernah dikatakan oleh Umar bin Khattab mengenai ayat terakhir mengenai riba. Ibnu Hazm meriwayatkan dalam al-Muhalla, bahwa Umar bin Khattab pernah berkhutbah:

"Demi Allah, sesungguhnya kami tidak mengerti, barangkali kami memerintah kalian dengan sesuatu yang layak bagi kalian, dan barang kali kami juga melarang kalian untuk tidak melakukan sesuatu yang tidak layak bagi kalian. Ayat yang terakhir diturunkan kepada Rasulullah adalah ayat tentang riba, tidak lama kemudian beliau wafat, sebelum sempat menjelaskannya kepada kita, maka tinggalkanlah sesuatu yang meragukan kalian, dan kerjakan apa yang tidak meragukan." 42

Dalam riwayat Imam Ahmad r.a. “... Ayat yang terakhir diturunkan adalah ayat yang menerangkan tentang riba. Sesungguhnya Rasulullah sampai beliau wafat tidak pernah menafsirkan ayat tentang riba, maka tinggalkanlah riba dan raibah (keraguan)." 43

\section{b. Interpretasi Riba Berdasarkan Konteks}

Melihat beberapa konteks pelarangan riba di atas, Saeed mencoba merumuskan beberapa hal mengenai riba.

Pertama, Aspek moral sebagai alasan pengharaman riba. Menurut Saeed, pengharaman riba berdasarkan konteks moral merupakan hal yang paling masuk akal. Hal ini dikarenakan, institusi riba pra-Islam memiliki kecenderungan untuk membuat debitur terjerat utang. Makanya, ketidakmungkinan untuk melunasi utang adalah kemungkinan untuk menjadi budak atau buruh ikatan. Karena masyarakat Arab pra-Islam tidak ada undang-undang yang mengatur untuk menccegah kreditur dari memaksa debitur untuk menjadi buruh ikatan. Berbeda dengan sekarang, para debitur pada umumnya, tidak seperti debitur zaman praIslam, bersandar pada pendapatan masa depan yang bisa diprediksi untuk melunasi utang-utangnya, baik berdasarkan pekerjaan ataupun

41 Ibid., hal. 35.

42 Ibnu Hazam az-Zhahiri, Muhalla bi al-Āsīar (Beirut: Dār al-Fikr, t.t.), VII: 414.

43 Ahmad bin Hambal, Musnad al-Imām Ahmad bin Hambal, Cet. 1 (ttp.: Muassasah alRisālah, 2001), hal. 361. 
dari pendapatan yang mendatang yang mungkin dari bisnis atau sumbersumber lainnya. ${ }^{44}$

Melihat kondisi masyarakat pada masa itu, dimana pemenuhan kebutuhan sehari-hari saja adalah masalah yang umum. Pekerjaan dan pendapatan tidak menentu. Maka wajar saja Al-Qur'an mengharamkan riba, sebagai respon terhadap kondisi tersebut, agar orang-orang yang lemah secara ekonomi dan sosial tidak beruntung.

Kedua, apa yang diharamkan adalah riba pra-Islam. Melihat apa yang diriwayatkan oleh ath-Thabari menjelaskan bahwa riba yang diharamkan adalah pra-Islam, dan juga dapat disimpulkan darinya bahwa bunga ringan tidak diharamkan. Hal ini menurut Saeed berdasarkan pendapat Muhammad Abduh, Rasyid Ridha, dan Abd al-Razaq Sanhuri. Mendukung hal ini, Saeed mengutip pendapat Chibli Mallat:

Baik Muhammad Abduh maupun Rasyid Ridha tidak ada yang merasa nyaman dengan bunga yang diberikan kepada para deposan atas uang mereka, tetapi mereka berdua tampaknya mentolerir bunga jika pola mud̄àrabah dapat dirancang untuk melegitimasi bunga atas simpanan-simpanan para pekerja. ${ }^{45}$

Ketiga, kebutuhan sebagai alasan untuk mengizinkan bunga rendah. Menurut Saeed, riba pra-Islam (riba jahiliyyah) merupakan bentuk riba terburuk "serupa dengan bunga berlipat ganda saat ini" adalah haram tanpa pengecualian. Di lain pihak, karena riba penundaan (nasi'ah), riba penambahan $(f a d h l)$ dan riba pinjaman diharamkan untuk mencegah terjadinya riba pra-Islam, maka semua jenis ini mungkin saja dibolehkan untuk sementara, dalam hal 'kebutuhan' menurut tinkatnya kebutuhan. Kemudian hukum harus menetapkan batas-batas bagi suku bunga, metode pembayaran, dan total yang harus dibayar sehingga bisa dibuat estimasi apa yang diperlukan bagi setiap kasus tertentu. ${ }^{46}$ Mengutip pendapat Sanhuri:

Dalam suatu Sistem ekonomi kapitalis, modal dimiliki oleh individu-individu, lembaga-lembaga, dan bank-bank; modal tidak dimiliki oleh pemerintah. Ada kebutuhan umum bagi pengusaha untuk mendapatkan modal guna investasi... Selama ada kebutuhan untuk mendapatkan modal dengan cara peminjaman, dan modal tersebut tidak dimiliki oleh pemerintah, bunga atas modal

\footnotetext{
${ }^{44}$ Saeed, Menyoal..., hal. 37-38

45 Ibid., hal. 63.

46 Ibid., hal. 64-65.
} 
itu dengan batas-batas yang dinyatakan adalah halal, sebagai pengecualian dari pengharaman yang asli. Individu memiliki modal, yang ia tabung dengan kerja keras dan usahanya; ia memiliki kewajiban untuk tidak berbuat zalim dan hak untuk tidak dizalimi. ${ }^{47}$

Keempat, Pinjaman untuk konsumsi sebagai alasan dibolehkannya bunga. Melihat konteks turunya ayat-ayat pengharaman riba, yaitu, untuk membebaskan penderitaan kaum miskin, orang-orang yang melarat, dan mereka yang terjebak hutang, maka pengharaman riba dari sudut pandang ini adalah terkait dengan pinjaman untuk konsumsi. Karena tidak terdapat bukti untuk pinjaman untuk tujuan-tujuan produksi dalam sekala yang luas pada zaman pra-Islam. Dari riwayat-riwayat dalam tafsir ath-Thabari, kata Saeed, tidak satu pun menyebut adanya atau komoditas yang dipinjam adalah untuk investasi.

\section{Prinsip Bagi Hasil: Muḍārabah dan Musyārakah}

Teori perbankan Islam tahun 1960-an membayangkan bahwa kegiatan investasi bank Islam mesti didasarkan pada bagi-hasil (profit and loss sharing-PLS), yang bergantung pada konsep muḍarabah dan musyārakah. Teori ini berpendapat bahwa bank Islam akan menyediakan sumber daya keuangan yang luas kepada peminjam atas dasar pembagian risiko, tidak seperti pembiayaan berbasis bunga di mana peminjam mengasumsikan semua risiko. Namun, dalam praktiknya, bank-bank Islam umumnya telah menyadari bahwa PLS, sebagaimana yang dibayangkan oleh teori, tidak dapat dimanfaatkan secara luas di perbankan syariah karena risiko yang dijalankan pada sebuah perbankan. Kesadaran ini telah menyebabkan bank-bank Islam untuk menemukan cara membatasi penerapan kedua konsep PLS dan mengubah konsep tersebut hampir tanpa resiko. ${ }^{48}$

Sebagaimana yang dipahami syariah, mud̄ārabah (muqāradhah-dalam bahasa orang Iraq) merupakan konsep kunci dari bagi hasil. Menurut fuqaha'

\footnotetext{
47 Ibid.

48 Saeed, Idealism..., hal. 90.
} 
mudārabah berarti, "menyerahkan harta kepada orang lain untuk diperniagakan dengan keuntungan dibagi diantara keduanya." 49

Al-Qur'an tidak pernah berbicara langsung mengenai muḍa rabah, meskipun ia menggunakan akar kata ضرب, dimana dari akar kata tersebut digunakan sebanyak lima puluh delapan kali, namun yang paling mendeketai adalah yang menunjukkan arti "perjalanan" atau "perjalanan untuk tujuan dagang." 50 Namun, mudārabah diakui oleh para ulama, ia telah di praktikan pada zaman jahiliyyah, dan kemudian tetap dipraktikan setelah Islam datang. Diriwayatkan oleh Abu Na'im, bahwa Rasulullah memperniagakan harta Khadijah-sebelum Rasulullah menikahinya-(dengan cara muḍ̄rabah) sekitar satu tahun dua bulan ke negeri Syam ditemani budak Khadijah, Maisyarah. ${ }^{51}$ Dalam sebuah riwayat Ibnu Abbas berkata:

Bahwa ayahnya Abbas bin Abdul Muthalib me-mudārabah-kan hartanya dengan memberikan syarat tidak boleh mengarungi lautan, tidak boleh melewati lembah, dan tidak boleh dibelanjakan ke hewan ternak..., jika melakukan demikan maka harus ada jaminan, lalu sampailah hal ini kepada Rasulullah, lalu membolehkannya. ${ }^{52}$

Akad mud̄ārabah memberikan kebebasan muḍ̄arib untuk menjalankan usaha, pemilik modal ( $r a b b u l$ māl) tidak ikut campur dalam menjalankan usaha. Modal mud̄arabah tidak boleh berupa hutang yang dipinjam mudarib pada saat dilangsungkannya kontrak mudārabah. Tak satupun dari empat mazhab fiqh Sunni yang untuk menjalankan mudārabah berdasarkan pengertian bahwa modal kongsi adalah hutang calon mudàrib kepada investor. ${ }^{53}$ Kemudian para fuqaha pun tidak mensyaratkan muḍarib memberikan jaminan kepada rabbul māl.

Namun dalam praktiknya di perbankan Islam, Saeed melihat, kontrak mudārabah digunakan untuk tujuan dagang jangka pendek dan untuk suatu kongsi khusus, ${ }^{54}$ dimana tidak ada transfer dana tunai yang diberikan kepada muḍārib. Jumlah modal di angsur ke dalam rekening muḍārabah yang oleh bank

49 Muhammad Șalah Muhammad aṣ-Șāwi, Musykilah al-Istisymār fi al-Bunūk al-Islamīyah wa Kaifa 'Alijuhā al-Islām (Tiklis: Dar al-Wafa', Cet.1, 1990), hal. 28.

50 Saeed, Menyoal..., hal. 77.

51 Syamsu ad-Dīn ar-Ramlī, Nihāyah al-Muhtāj fì Syarhi al-Manhāj (Beirut: Dār al-Fikr, 1984), V: 219.

52 Aș-Șawi, Musykilah..., hal. 27.

53 Saeed. Menyoal..., hal. 81.

54 Ibid., hal. 83. 
dibuka untuk tujuan pengelolaan muḍārabah. Karena umumnya muḍarabah untuk tujuan pembelian barang-barang tertentu, maka bank sendirilah yang melakukan pembayaran kepada penjual. ${ }^{55}$ Dalam ketentuan kontrak, peran mudārib dibatasi untuk memenuhi syarat-syarat kontrak, melalui ketentuan ini juga, perbankan Islam menuntut sejumlah jaminan. Namun mereka menegaskan bahwa jaminan tidak dibuat untuk memastikan kembalinya modal, tetapi untuk memastikan bahwa kinerja muḍārib sesuai dengan syarat-syarat kontrak. ${ }^{56}$ Lewat bermacam-macam cara bank Islam hampir menghilangkan semua ketidak-pastian yang mungkin terjadi dalam kongsi mudārabah murni. Risiko aktuarial dalam kongsi muḍ̄rabah seperti digunakan dalam perbankan Islam dapat diukur dan dipastikan. Padahal dalam teori, bank mendapatkan laba dan juga rugi, tetapi dalam praktik, dikarenakan sifat kontrak muḍ̄rabah bank Islam dan syarat-syarat yang ada di dalamnya, kerugian semcam ini mungkin akan jarang sekali terjadi. Untuk alasan inilah, dapat dikatakan bahwa mudāarabah bank Islam sedikit berbeda dengan penyelengaraan investasi berisikp rendah mupun investasi bebas-risiko manapun. ${ }^{57}$ Dari sini dapat diperoleh bahwa kontrak mudārabah dari bank syari'ah agak berbeda dari kontrak muḍārabah seperti yang digambarkan oleh fiqh klasik, atau seperti yang dibayangkan oleh para teoritisi perbankan Islam, sebagai pembiayaan modal ventura / atau industri pembiayaan untuk pembangunan. ${ }^{58}$

Konsep penting lainnya dalam sistem bagi hasil adalah musyārakah. AlQu'ran menggunakan akar kata isitlah musyārakah, yaitu شرك sebanyak 170 kali, walaupun tak satupun dari ayat ini dengan arti kemitraan dalam suatu kongsi bisnis. Namun demikian, berdasarkan sejumlah ayat al-Qur'an, khususnya surah an-Nisa: 12 dan Shād: 34, maupun berdasarkan sejumlah riwayat yang dinisbatkan kepada Nabi Muhammad dan para sahabatnya, para fuqaha membenarkan keabsahan musyārakah dalam kongsi bisnis. ${ }^{59}$ Dalam sebuah hadits yang diriwayatkan oleh Abu Daud dan al-Hakim, dari Abu Hurairah r.a. berkata: Bersabda Rasulullah s.a.w., "Allah Ta'ala berfirman: Aku adalah

\footnotetext{
55 Ibid., hal. 84.

56 Ibid., hal. 85.

57 Ibid., hal. 87.

58 Ibid., hal. 88.

59 Ibid.
} 
yang ketiga dari dua orang yang bersyerikat selama tidak berkhianat salah seorang dari mereka, maka jika berkhianat, Aku keluar dari persyerikatan tersebut. ${ }^{60}$

Musyārakah, sebagaimana yang dijelakan oleh International Islamic Bank for Investment and Development sebagai "metode pembiayaan terbaik dalam bank Islam", adalah suatu metode yang didasarkan pada keikutsertaan bank dan pencari-pembiayaan (mitra potensial) untuk suatu proyek tertentu, dan akhirnya, keikutsertaan dalam menghasilkan laba atau rugi. ${ }^{61}$ Dalam Fiqh, musyārakah umumnya digunakan dalam usaha yang hasilnya tidak pasti, artinya dalam bisnis yang nyata. Lazimnya dalam kontrak musyārakah diikuti oleh para mitra yang setara, artinya, kedua belah pihak sepakat dengan syaratsyarat kontrak, dan salah satu pihak tidak boleh mendiktekan syarat-syarat tersebut kepada pihak yang lain, kemudian sejak "mitra" dianggap sebagai orang yang dipercaya, maka tidak ada jaminan yang diizinkan. ${ }^{62}$

Dalam perbankan Islam ada beberapa bentuk musyārakah yang dipraktikkan seperti musyārakah dagang, partisipasi berkurang, dan partisipasi permanen, pada umumnya lebih menonjol dalam bentuk komersial jangka pendek, namun ada juga untuk keikutsertaan dalam investasi proyek-proyek jangka menengah hingga jangka panjang yang biasanya terkait erat dengan perdagangan barang tertentu. ${ }^{63}$

Saeed melihat, Musyārakah komersial memungkinkan bank untuk memulihkan modal, ditambah keuntungan, tanpa ada ketidakpastian, atau risiko. Mitra dibatasi dalam tindakannya ditentukan oleh kontrak secara terperinci, sehingga tidak memberikan kebebasan kepada mitra untuk melaksanakan musyārakah dalam arti sebenarnya seperti yang diatur oleh fiqh. ${ }^{64}$ Menurut Saeed, dari klausul kontrak bank-bank Islam, tanpak si mitra lebih seperti seorang wakil dari bank yang fungsinya adalah menjual barang-barang dengan harga yang telah ditetapkan oleh bank. Dengan demikian, saham bank berupa modal berikut keuntungannya sangat dilindungi oleh berbagai bentuk

60 Sunan Abu Daud, Hadis No. 3383, Juz. 3 (Beirut: Maktabah al-'Asriyyah,tt.), hal. 256. Dan Al-Hakim, Mustadrak Ala Șaḥiḥain, hadits No. 2322, juz. 2 (Beirut: Dār al-Kitāb alIlmiyyah, 1411 H/1990 M), hal. 60.
61 Saeed, Menyoal..., hal. 93.
62 Saeed, Idealism..., hal. 91.
63 Saeed, Menyoal..., hal. 93.
64 Saeed. Idealism...., hal. 91. 
jaminan dan klausul kontrak. Berbagai bentuk jaminan dan syarat-syarat terperinci, sehingga bank sepertinya membebani sejumlah besar resiko yang terkait pengelolaan kepada mitranya. ${ }^{65}$

Saeed menemukan ada beberapa hal yang menyebabkan perubahan konsep klasik muḍārabah dan musyārakah. Diantaranya, (1) rendahnya standar moral dikebanyakan masyarakat Muslim tidak memungkinkan penggunaan PLS dalam skala yang luas sebagai mekanisme investasi. ${ }^{66}$ (2) Meskipun PLS dalam bentuk mud̄̄rabah dan musyārakah adalah alat yang canggih untuk mengelimir bunga dalam bisnis-bisnis pribadi dan pembiayaan jangka pendek, kemampuan kerjanya di dunia kredit kelembagaan sangatlah sulit. ${ }^{67}$ (3) Keterlibatan bank yang begitu tinggi sehingga menciutkan pengusahanya yang menginginkan kebebasan bermanuver, dimana bank juga secara terus menerus harus mengawasi sehingga secara teknis tidak efisien. ${ }^{68}$ Dengan berbagai kendala tersebut dapat dipastikan konsep PLS tidak begitu populer dalam perbankan Islam.

\section{Prinsip Jual Beli: Murābaḥah}

Problem-problem praktis yang dihadapi perbankan Islam dalam menerapkan konsep bagi hasil mengakibatkan penurunan terhadap penggunaannya, sehingga mekanisme-mekanisme pembiayaan mirip bunga terus tumbuh. Ini berarti bahwa di antara produk-produk pembiayaan yang diterapkan di perbankan Islam terjadi kesenjangan antara yang satu dengan yang lain. Saeed menyebut mekanisme mirip bunga ini adalah murābaḥah. ${ }^{69}$ Karena bisnis ini nyaris tanpa risiko, ia pun menjadi bisnis yang paling populer dan disenangi oleh bank-bank Islam, menduduki sampai 70\% usaha bank Islam, dan meminimalisir posisi PLS hingga sampai 30\%-0\%. ${ }^{70} \mathrm{Hal}$ ini dapat dibuktikan dari beberapa hasil survei, ternyata bank-bank syari' ah pada umumnya, banyak menerapkan muräbahah sebagai metode pembiayaan mereka yang utama, meliputi kurang lebih 75\% dari total kekayaan mereka. Sejak awal tahun 1984, di Pakistan,

\footnotetext{
65 Ibid.

${ }^{66}$ Saeed, Menyoal..., hal. 106.

67 Ibid., hal. 107

68 Ibid., hal. 107-109.

69 Ibid., hal. 118.

70 Ibid., hal. ix.
} 
pembiayaan jenis murābahah mencapai sekitar $87 \%$ dari total pembiayaan dalam investasi deposito PLS. Sementara itu, di Dubai Islamic Bank, pembiayaan murābahah mencapai 82\% dari total pembiayaan selama tahun 1989. Bahkan, di Islamic Development Bank (IDB), selama lebih dari sepuluh tahun periode pembiayaan, $73 \%$ dari seluruh pembiayaannya adalah murābahah. ${ }^{71}$

Menurut Saeed, hal ini menunjukkan kegagalan bank Islam untuk menjadi bank PLS seperti yang dibayangkan para pencetusnya di satu sisi, dan di sisi lain menunjukkan ketidak-logisan dan ketidak-konsisten bank Islam akibat menerapkan produk muräbahah dengan menolak transaksi finansial yang menggunakan bunga. Hal ini lah yang membuat Saeed menduga adanya time value of money dalam pembiayaan berbasis muräbahah, namun hal tersebut oleh praktisi perbankan Islam tidak diakuinya, karena kalau diakui akan mengarah kepada pengakuan adanya bunga atau riba. ${ }^{72}$ Saeed mengakui tentang kebolehan murābahah, hanya saja ia menilai murābahah yang dipraktikan perbankan Islam tidak jauh beda dengan konsep bunga.

Berikut ini akan dijelaskan beberapa pandangan Saeed terhadap praktik murābahah dalam perbankan:

\section{a. Perbandingan antara Pembiayaan Murābaḥah dan Bunga Tetap}

Saeed melihat ada dua hal yang menjadi perhatian utama Perbankan Islam dalam membedakan pembiayaan murābahah dan bunga. Pertama, perbankan Konvensional memperoleh suku bunga yang sedang berlaku yang dikaitkan dengan pokok pinjaman dan jatuh tempo, kemudian perbankan konvensional tidak peduli terhadap harga barang yang menjadi kebutuhan nasabah. Berbeda dengan muräbahah, dimana bank Islam memastikan bahwa si nasabah mengetahui total harga barang sebelumnya. Kedua. Suku bunga bisa berupa bunga tetap atau suku bunga tak tetap. ${ }^{73}$

Saeed menyatakan, apakah suku bunga tetap atau tidak tetap barangkali tidaklah penting dalam tempo yang sangat pendek, karena perubahan besar dalam suku bunga umumnya tidak terjadi dalam tempo yang pendek. Hal

71 Anita Rahmawati, “Ekonomi Syari'ah: Tinjauan Kritis Produk Murābahah dalam Perbankan Syari'ah di Indonesia”, Jurnal La_Ribaī, No. 2 Vol. 1 (Desember 2007), hal. 188.

72 Ibid., hal.

73 Ibid., hal. 128. 
penting untuk diingat karena kontrak murābahah umunya bersifat jangka pendek. Dalam hal bunga, suku bunga yang diberlakukan akan tergantung kepada kebutuhan bank untuk mendapatkan keuntungan riil, inflasi, ketidak pastian tingkat inflasi dimasa mendatang, preferensi likuiditas serta permintaan akan pinjaman, kebijakan moneter, dan bahkan suku bunga luar negeri. Namun Saeed melihat faktor-faktor yang mempengaruhi suku bunga juga menjadi faktor-faktor yang sama pada mark-up murābahah. ${ }^{74}$

Pada akhirnya, kata Saeed, alih-alih lebih murah, biaya dalam pembiayaan murābahah dapat lebih mahal. Pembiayaan berdasarkan bunga, si bankir cukup diberi data finansial yang relevan untuk menilai posisi keuangan nasabah, dan untuk menilai proyek yang dimohonkan pembiayaan. Penelitian pasar yang memakan biaya, kertas kerja yang dihasilkan dari memproses permintaan dokumen, pemantauan yang terus menerus terhadap perkembangan pernjualan barang-barang murābahah setelah diberikan ke nasabah, kesemuanya ini memerlukan keterlibatan yang lebih dari personil bank, jika dibandingkan dengan pembiayaan berbasis bunga. Kenaikan biaya akan tercermin dalam harga total barangbarang murābahah..$^{75}$

\section{b. Kontrak Murābahah bersifat formalitas}

Melihat peran perbankan Islam dalam akad murābahah, Saeed menyimpulkan bahwa lebih tepatnya perbankan Islam sebagai "pembiaya" bukan sebagai "penjual" barang. Bank tidak memegang barang, tidak pula mengambil risiko atasnya. Kerja bank hampir semuanya terkait dengan penanganan dokumen-dokumen terkait, sehingga kontrak penjualan hanya sekedar formalitas. ${ }^{76}$

Lebih lanjut menurut Saeed, bank tidak perlu menungu tibanya barang untuk diperiksa sebelum diserahkan kepada pembeli. Justru, kondisi barang tidak terlalu dipedulikan oleh bank karena tanggung jawab pembelilah untuk mengecek spesifikasinya. ${ }^{77} \mathrm{Hal}$ ini menunjukkan bahwa meskipun murābahah tampak sebagai kontrak jual beli dalam perbankan

\footnotetext{
74 Ibid., hal. 129.

75 Ibid., hal. 131.

76 Ibid., hal. 142.

77 Ibid., hal. 143.
} 
Islam, murābahah adalah suatu jenis pembiayaan berdasarkan keuntungan yang ditetapkan di muka, yang tidak jauh berbeda dengan pembiayaan berdasarkan bunga. ${ }^{78}$

\section{c. Keuntungan Murābaḥah, Bunga, dan Riba.}

Menurut Saeed, bank-bank Islam tampaknya hanya memperhatikan kecocokan "kulit" dengan ajaran hukum Islam sebagai determinan terpenting keislaman operasi mereka, seperti yang ditunjukkan dalam transaksi murābahah, teknik pembiayaan terpenting perbankan Islam saat ini. Dikarenakan al-Qur'an menghalalkan jual beli dan tidak menetapkan batas laba (mark-up), hal ini membuat perbankan dengan bebas menetapkan mark-up pada kontrak murābaḥah. ${ }^{79}$

Bank-bank Islam cenderung menafsirkan riba sebagai sesuatu yang umumnya terjadi dalam konteks finansial, yaitu kewajiban-kewajiban kontraktual untuk membayar tambahan oleh peminjam dalam utangpiutang. Menurut Saeed, teknik mark-up dan batas laba dalam perdagangan dan sewa tidak lain adalah bunga dengan nama yang berbeda, bahkan tidak terlihat perbedaan dari sudut pandang ekonomi, keduanya samasama mengunakan nilai waktu uang. Perbedaan keduanya hanyalah soal hukum, dasar bunga adalah kontrak utang-piutang, sementara dasar markup datau sewa adalah kontrak jual-beli atau kontrak penyewaan. ${ }^{80} \mathrm{Hal}$ yang sama juga di ungkapkan oleh Mahmoud A. el-Gamal mengenai hal ini:

Faktanya dua terminologi ini (riba dan bunga) sangat jauh dari dari kesamaan, ahli fiqih kontemporer yang konservatif tidak mempertimbangkan segala bentuk apa yang oleh ahli ekonomi dan pembuat undang-undang disebut bunga sebagai riba yang haram. Sebagai contoh metode keuangan Islam yang bebas riba seperti mark-up jual-beli kredit (muräbahah) dan sewa (ijārah) menunjukkan pembiayaan yang tidak "bebas bunga." 81

Memang benar murābahah secar kasat memang tampak seperti bunga, bahkan tidak terasa bahwa ia berbeda dari bunga. Asumsi ini menurut

78 Ibid.

79 Ibid.

80 Ibid., hal. 144

81 Mahmoud A. El-Gamal, Islamic Finance: Law, Economics, and Practice (Cambridge: Cambridge University, 2006), hal. 51. 
penulis umum dirasakan para nasabah perbankan syariah. Hal ini juga disimpulkan oleh Asmuni Mth., ia mengatakan:

Meskipun sampai saat ini terkadang masyarakat "belum merasakan perbedaan antara keduanya (perbankan Islam dan konvensional)." Mengapa? Salah satu jawabannya adalah karena praktik perbankan syari'ah "belum" memposisikan dirinya sebagai alternatif pilihan di tengah persaingan dengan perbankan konvensional. Tipisnya perbedaan ini diakui atau tidak membuat perbankan syari'ah sangat lamban. ${ }^{82}$

Sebagai kesimpulan, jika kita lihat pendapat Saeed, bahwa perbankan Islami jauh dari syari'ah, bahkan tidak diperlukan. Namun menurut penulis, pendapat Saeed di atas harus dikritisi. Ada hal-hal yang bersifat asasi seperti cakupan makna riba tidak bisa berubah agar kepastian hukum terjaga. Kemudian ada hal-hal yang bersifat teknikal (furu') seperti jaminan pada pembiayaan yang bisa menyesuaikan berdasarkan konteks.

\section{Penutup}

Abdullah Saeed menawarkan pendekatan maqashid-kontekstual dalam menjelaskan prinsip-prinsip keuangan Islam, karena pendekatanini menurutnya lebih berorientasi moral. Sebagai hasilnya, riba diharamkan karena eksploitasi terhadap orang miskin, sementara bunga dibolehkan karena seperangkat aturan yang ditetapkan oleh pemerintah telah menghalangi perbankan untuk berbuat eksploitasi. Saeed juga menilai bahwa perbankan Islam bergerak ke arah yang pragmatis, sejumlah aturan yang ditetapkan dalam PLS hanya untuk melindungi perbankan. Sehingga yang terjadi adalah berbagi hasil namun tidak berbagi resiko. Selanjutnya Saeed melihat bahwa perbankan Islam tidak lebih baik dari perbankan konvensional. Karena kenyataannya, praktik perbankan Islam juga menerapkan "model transaksi keuangan yang seperti bunga" yaitu muräbahah. Keuntungan muräbahah bersifat pasti dan dipengaruhi oleh waktu, tidak jauh beda dengan konsep bunga yang dicela. Perbedaan hanya terlihat pada akad saja, tapi tidak dalam praktik.

Dari fakta-fakta yang dipaparkan Saeed tentang praktik perbankan Islami, memang terlihat bahwa perbankan Islam bergerak kearah yang pragmatis,

82 Asmuni Mthal., "Produk Perbankan Syriah: Antara al-Minhāj al-Raddi dan al-Minhāj al-Maqshadī", Buletin al-Islamiyah, No. 01 Tahun XIX (Februari 2013), hal. 46. 
bahkan kehilangan ruh keislamannya. Dimana konsep dasar dari perbankan Islam adalah "tolong-menolong dalam kebaikan" sudah mulai terasa jauh, yang lebih menonjol aspek bisnisnya. Bahkan sering kita lihat lebel "Islami" atau "syari'ah" hanya lebih kepada nilai jualnya dari pada spiritnya. Bahkan tidak sedikit korporasi kapitalis mengambil bagian dalam bisnis ini hanya demi keuntungan semata.

\section{DAFTAR PUSTAKA}

Asmuni, 2013, "Produk Perbankan Syriah: Antara al-Minhāj al-Raddi dan alMinhāj al-Maqshadī", Buletin al-Islamiyah, No. 01 Tahun XIX.

Al-Arabi, Muhammad 'Abdullah, tt., Muhäḍarāt fi al-Nażm al-Islamiyyah, Kairo: Mațba' ah al-Syurq al-'Arabi.

Ayub, Muhammad, 2009, Understanding Islamic Finance: A-Z Keuangan Syari'ah, Jakarta: Gramedia.

Chapra, M. Umar, 2000, Sitem Moneter Islam, Jakarta: GIP dan Tazkia Cendekia.

Daud, Abu, Tanpa Tahun, Sunan Abu Daud, Beirut: Maktabah al-'Asriyyah.

Furchan, Arif dan Agus Maimun, 2005, Studi Tokoh: Metode Penelitian Mengenai Tokoh, Yogyakarta: Pustaka Pelajar.

Al-Hakim, Mustadrak 'Ala Shahihain, Juz. 2, Beirut: Dār al-Kitāb al-Ilmiyyah.

Hambal, Ahmad bin, 2001, Musnad al-Imām Ahmad bin Hambal, Cet. 1, Muassasah al-Risālah.

Haron, Sudi dan Wan Norsofiza Wan Azmi, 2009, Islamic Finance and Banking System: Philosphies, Prinsciples, and Practices, Shah Alam: McGraw-Hill. Hitti, Philip K., 2006, History of The Arabs, terj., Jakarta: Serambi.

Ibrāhim, Isa 'Abduh, 1977, al-Ribā wa Dawruhu fì Istiglāl Muwārad as-Syu'ub, Kairo: Dār al-I'tisham.

Islahi, A. A., 1997, Konsepsi Ekonomi Ibnu Taymiyah, Surabaya: Bina Ilmu.

Mannan, Muhammad Abdul, 1999, Teori dan Praktik Ekonomi Islam, Yogyakarta: Dana Bakti Wakaf.

Manzur, Ibnu, 1414 H, Lisānul 'A rab, Jilid XI, Beirut: Dār al-Shādir.

Quthb, Sayid, 2000, Tafsir F̄̄ Zhilālil-Qur'an: Dibawah Naungan al-Qur'an, Jakarta: Gema Insani Press. 
Rahman, Fazlur, 1964, "Riba and Interest”, dalam Journal of Islamic Studies. No. 3 Vol. 1.

985, Islam dan Modernitas, Tentang Transformasi Intelektual, Bandung: Pustaka.

Rahman, Ramadhān Hāfidz Abdur, 2005, Mauqif as-Syar iyah al-Islāmiyah min al-Bunūk wa al-Mu'āmalāt al-Mashrafiyah wa al-Ta'minn (Kairo: Dār alSalām.

Rahmawati, Anita, 2007, Rahmawati, “Ekonomi Syari’ah: Tinjauan Kritis Produk Murābahah dalam Perbankan Syari'ah di Indonesia", Jurnal La_Ribaī, No. 2 Vol. 1.

Al-Ramli, Syamsu al-Dīn,1984, Nihāyah al-Muhtāj fì Syarhi al-Manhāj, Jilid V, Beirut: Dār al-Fikr.

Al-Rāzī, Fakhru al-Dīn, 1420, Mafātih al-Ghaib, Cet. III, Beirut: Dār Iḥyā'i alTurāts al-'Arabi.

Ridha, Rasyid, 1917, "Ribḥ Șunduq al-Barīd" dalam Majallah al-Manār, Juz 19. Saeed, Abdullah, 1988, "Idealism and Pragmatism in Islamic Banking: The Application of Shari'ah Principles and Adjustments", dalam Journal of Arabic, Islamic and Midle Eastern Studies, No. 2, Vol. 4.

, 2004, Islamic Banking and Finance: In Serch of a Pracmatic Model dalam Islamic Perspectif on the New Millenium, Virgina Hooker dan Amin Saikal (Ed.), Singapore: Institute of Southeast Asian Studies.

2006, Interpreting the Qur'an: Toward a Contemporary Approach, Madison Ave: Routladge.

, 2008, The Qur'an: an Introduction, London: Routledge.

, 2008, Menyoal Bank Syariah, Kritik Interpretasi Bunga Bank Kaum NoeRevivalis, Jakarta: Paramadina.

El-Sahker, Ahmed A. F. dan Rodney Wilson, 2006, Islamic Economics: A Short History, Leiden: Brill.

Al-Shawi, Muhammad Shalah Muhammad, 1990, Musykilah al-Istisymar fi alBunuk al-Islamiyah wa Kaifa 'Alijuha al-Islam, Kairo: Dar al-Mujtama.

Siddiqi, Muhammad Nejatullah, 1984, Bank Islam, Bandung: Penerbti Pustaka. 2004, Riba, Bank Interest and Rationale of Its Prohibition, Jeddah: Islamic Reseach and Training Institute. 
Sulaiman, Majdi Abd al-Fatāh, 1984, "al-Fāidah al-Mashrafiyah fi Nazhri alIslām wa Mawqif al-'Ulamā minha", dalam Majallah bi al-Dirāsāt alIslāmiyah wa bi Syu'ūni al-Tsaqāfah wa al-Fikr, No. 243 Vol. 2.

Ath-Thabari, Ibn Jarīr, 2001, Jāmi'i al-Bayān 'an Ta'wīl Ayi al-Qur'ān, Jilid V, Dār Hajr.

Tim Penulis MSI-UII, 2008, Menjawab Keraguan Berekonomi Syariah, Yogyakarta: MSI-UII dan Safiria Insania Press.

Ustmani, Muhammad Taqi', 1998, An Introduction to Islamic Finance, Karachi: Idarat al-Ma'arif.

Az-Zhairi, Ibnu Hazam al-Andalusi, tt., Muhalla bil al-Ātsār, Beirut: Dār al-Fikr. Zahrah, Muhammad Abu, Tanpa Tahun, Buhūts fi al-Ribā, Kairo: Dār al-Fikr al-'Arabī.

Al-Zuhaili, Wahbah, 2009, al-Fighu al-Islāmī wa Adillatuhu, Jilid IV, Damaskus, Dār al-Fikr. 